\title{
HUBUNGAN ANTARA KEMATANGAN BERAGAMA DAN KECERDASAN EMOSIONAL DENGAN DAYA TAHAN TERHADAP STRES
}

\section{Iin Tri Rahayu}

Fakultas Psikologi Universitas Islam Negeri (UIN) Malang, Gedung IImu-flmu Sosial ht.1, Jl. Gajayana 50 Malang 65144 Telp. 0341-551354, 558882

Faks. 0341-572533, 0341-558882.

\section{Abstract}

Adolescent age is transition time. There are many changes in the transition time. It is also genenating a certrin difficult problems. The unready adolescent in respons their change in life will make them stress. Therefore, the research aism to know about the relationship between religion maturity and stress resistance, and relationship between emotional intelligence and stress resistance. Sixty subjects were collected from psychology departement of UIN Malang student. The collecting of data sampling was based on the frame of purpossive sampling. The used scale was religion maturity scale, emotional intelligence scale, and stress resistance scale. Data anaysis used in this study was product moment correlation. The result of this study is that there is a possitive correlation between religion maturity and stress resistance $(p=0.029)$, and moreover a positive correlation between emotional intelligence and stress resistance can be recovered here $(p=0.000)$.

Key words: religion maturity, emotional intelligence, stress resistance 


\section{Pendahuluan}

Berita-berita yang disuguhkan baik oleh media cetak ataupun media elektronik akhir-alhir ini nyaris tidak pernah lepas dari pembahasan tentang berbagai kejadian yang mencemaskan seperti, kekerasan, kejahatan, kriminalitas, ketidak adilan, pelecehan, pemerkosaan, pelanggaran hak, kerusuhan, bencana alam, pengangguran, dan penggusuran.

Maraknya kejadian di atas membuat masyarakat sadar bahwa itu terjadi disebabkan karena adanya gangguan psikologis yang diderita oleh sebagian masyarakat. Kesadaran akan pentingnya pengelolaan aspek-aspek psikologis dewasa ini semakin meningkat. Pengelolaan aspek-aspek psikologis ini bertujuan dalam rangka menangani gangguan-gangguan psikis yang belakangan ini banyak bermunculan, seperti stres, depresi dan frustrasi, yang merupakan stimulus atau emosi terkondisikan sehingga dapat menyebabkan munculnya tingkah laku yang tidak terkontrol (Koswara, 1988).

Hawari (1997) mengungkapkan bahwa sebagian masyarakat menyangka moderenisasi serta merta membawa kesejahteraan dan kebahagiaan. Masyarakat melupakan gejala di balik moderenisasi berupa agony of moderinization, yaitu azab sengsara karena moderenisasi. Hal ini adalah salah satu akibat dari mengabaikan aspek kepentingan rohani, termasuk agama. Salah satu hal penting yang harus diperhatikan dalam agama adalah masalah kematangan beragama. Menurut Jalaluddin (1997) bahwa seseorang yang memiliki kematangan beragama mampu mengenali atau memahami nilai agama yang terletak pada nilai-nilai leluhumya serta menjadikan nilai-nilai itu pedoman dalam bersikap dan bertingkah laku dalam kehidupan sehari-hari.

Kematangan beragama pada diri individu juga akan membawa indivu pada suatu keyakinan bahwa selain berhubungan baik dengan Tuhannya dia juga harus berhubungan baik dengan dirinya dan orang lain. Bisa menerima kekurangan dan kelebihan yang dimilikinya sekaligus menerima kekurangan dan kelebihan orang di sekitamya. Hal tersebut sesuai dengan dimensi kecerdasan emosional yang menyatakan bahwa orang yang 
memiliki kecerdasan emosional adalah orang yang bisa memahami keadaan dirinya, mengelola dirinya dan sekaligus bisa memahami orang lain.

Kecerdasan emosional merupakan salah satu faktor yang bisa membantu seorang indiividu dalam mengatasi berbagai permasalahan yang dihadapi dalam kehidupan sehari-harinya. individu yang memiliki kecerdasan emosional mampu menentukan dan memilih perilaku yang tepat dalam menghadapi berbagai macam persoalan yang dihadapi. Seorang individu yang memiliki kecerdasan emosional tinggi bisa memahami emosinya, bisa mengelola emosinya, bisa menyesuaiakan diri dengan orang lain dan lingkungan sekitarnya, dengan demikian orang yang memiliki kecerdasan emosional lebih tahan terhadap stres.

Dari uraian di atas maka penelitian ini bertujuan 1). untuk mengetahui adanya hubungan antara kematangan beragama dengan daya tahan terhadap stres pada mahasiswa Fakultas Psikologi UIN Malang. 2) mengetahui adanya hubungan antara kecerdasan emosional dengan daya tahan terhadap stres pada mahasiswa Fakultas Psikologi UIN Malang.

Manfaat yang dapat diambil dari penelitian ini adalah 1). secara teoritis, hasil penelitian akan menjadi informasi yang dapat memperkaya khasanah ilmu pengetahuan, khususnya psikologi, terutama tentang hubungan antara kematangan beragama dan kecerdasan emosional dengan daya tahan stres. 2) secara praktis, dapat dijadikan pedoman bagi berbagai pihak, yaitu: bagi orang tua menjadi bahan pertimbangan dalam memimbing remaja untuk menekankan pendidikan agama dan mengembangkan kecerdasan emosi untuk mengantisipasi terjadinya stres pada remaja. Bagi pemerintah dapat memberi perhatian khusus terhadap pentingnya aspek kematangan beragama untuk mengatasi maraknya masalah yang timbul akibatb era globalisasi

\section{LANDASAN TEORI \\ Kematangan Beragama}

Menurut Allport (dalam Batson dkk, 1989), kematangan diartikan sebagai pertumbuhan kepribadian dan inteligensi secara bebas dan wajar 
seiring dengan perkembangan yang relevan. Salah satu bentuk dari kematangan mental adalah kematangan beragama. Allport (dalam Batson dkk, 1989) memperkenalkan konsep kematangan beragama yang diartikan sebagai sentiment keberagamaan yang terbentuk melalui pengalaman, untuk merespon objek-objek konseptual dan prinsip-prinsip.yang dianggap penting dan menetap dalam kehidupan yaitu agama dan dilakukan secara sadar dalam bentuk kebiasaan-kebiasaan tertentu.

Allport (dalam Rahmat, 1994) mengemukakan bahwa kematangan beragama seseorang harus diukur dengan a Comprehensive Commitment (keterlibatan secara menyeluruh dalam seluruh ajaran agama yang dianut seseorang, oleh karena itu kematangan beragama seseorang tidak dapat diukur atau dilihat dari frekwensi seseorang dalam berkunjung ketempat ibadah saja. Individu yang menganggap agama sebagai suatu keyakinan dan kehidupan internal mereka akan menjadikan agama itu sebagai tujuan hidupnya (Allport dan Ross, dalam Monly, 1977).

Menurut Hurlock (1973) bahwa masa remaja merupakan masa transisi dari masa kanak-kanak ke masa remaja dan menuju ke dewasaannya. Pada masa ini akan timbul berbagai macam perubahan, baik pada aspek fisik, seksual, emosional, religi, moral, sosial, maupun intelektual, dengan demikian sebagian besar remaja mengalami ketidakstabilan dari waktu ke waktu sebagai konsekwensi dari usaha penyesuaian diri pada perilaku baru dan harapan sosial.

Menurut Darajat (1985) masa remaja adalah tahap bagi remaja untuk berusaha mencapai peningkatan akan kesempurnaan pribadinya, dan remaja berusaha mengembangkan kematangan keberagamaannya. Cara remaja menerima dan menanggapi pendidikan agama jauh berbeda dengan masamasa sebelumnya, selain itu, remaja berharap agama dapat menyelesaikan kegoncangan dan kepincangan yang terjadi dalam masyarakat.

Darajat (1978) juga mengemukakan bahwa sasaran pembinaan kehidupan beragama remaja dalam kampus adalah mereka yang sedang berada pada umur pembinaan terakhir yaitu berkisar umur 18-24 tahun. 
Pendapat Darajat tersebut diperkuat oleh Shelton (1991) yang menyatakan bahwa ketika memasuki perguruan tinggi, para remaja mendapatkan kemungkinan iman yang cukup matang dan reflektif. Para remaja mulai mempertanggungjawabkan ungkapan iman yang masuk akal dan logis. Remaja pada tingkat awal tidak hanya merasa butuh untuk memperdalam refleksi imannya, tetapi mereka juga membutuhkan keterbukaan pada pengalaman-pengalaman masa kini dan mendatang, dan remaja mulai menganggap serius beban pertanggungjawaban atas keterlibatan gaya hidup, iman, dan perikunya.

Menurut Starbuck (dalam Jalaluddin dan Ramayulis, 1993) bahwa perkembangan keagamaan pada remaja ditandai oleh beberapa faktor, yaitu perkembangan rohani dan jasmani sebagai berikut: (1) pertumbuhan pikiran dan moral, (2) perkembangan perasaan, (3) perkembangan sosial, (4) perkembangan moral, dan (5) sikap dan minat.

Menurut Jalaluddin (1997) bahwa individu yang memiliki kematangan beragama akan terlihat dari kemampuannya untuk memahami, menghayati serta mengaplikasikan nilai-nilai luhur agama yang dianutnya dalam kehidupan sehari-hari. Hal senada juga dikemukakan oleh Hurlock (1973) bahwa perkembangan keagamaan yang terjadi pada remaja dicirikan dengan menurunnya intensitas keraguan pada agama setara dengan kedewasaan diri dalam menghadapi masalah secara objektif dan memecahkannya tanpa emosi.

Berdasarkan uraian di atas dapat.disimpulkan bahwa individu yang memiliki kematangan beragama yang baik tercermin dalam sikapdan tingkah laku serta mampu menghayati, memahami dan mengamalkan nilai-nilai ajaran agama dalam kehidupan bermasyarakat.

Aspek-aspek yang terkandung dalam kematangan beragama, menurut Allport (dalam Batson dkk, 1984) meliputi :

\section{Diferensiasi}

Diferensiasi adalah mampu menerima agama yang dipeluknya secara observatif, objektif, reflektif-kritis, terbuka dan adanya penjabaran (Subandi,

Ulul Albab, Vol. 8 No. 2, 2007 


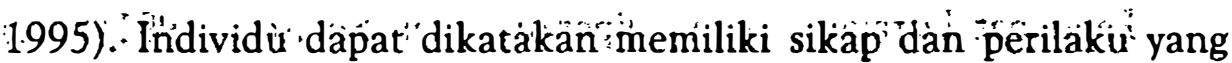

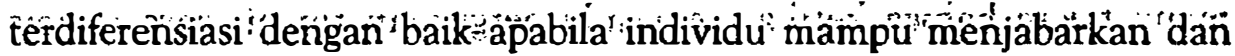

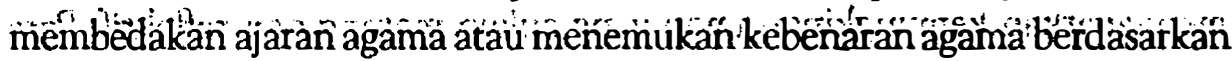

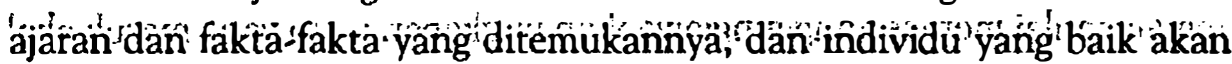

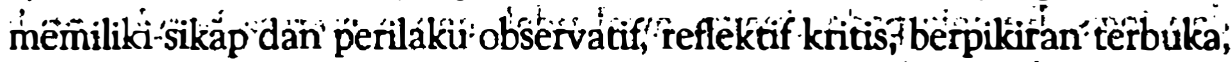

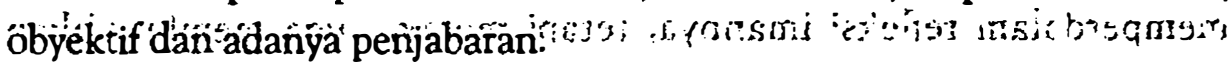

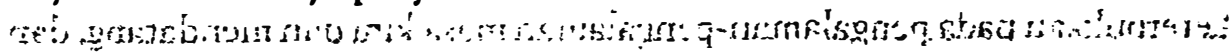

Dinamis an

Dinamis maksudnya adalah berperilaku hidup terkontrol, terarahkan, dán mengalami perubahan karena pengaruh agamanya: Individu yang

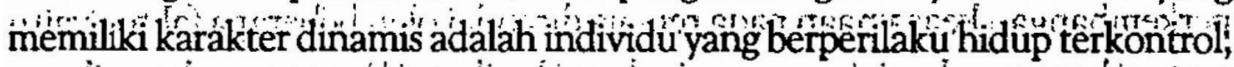

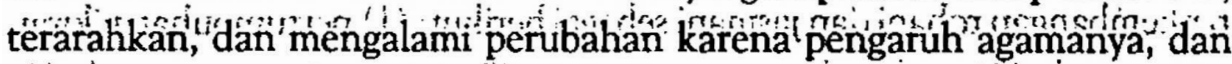
dalam kakter dinamis terdapat motivasi intrinsik untuk beragama, bersifát

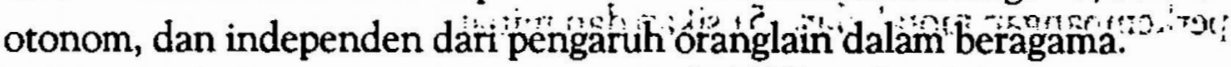

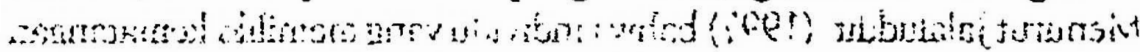

Könsistensi

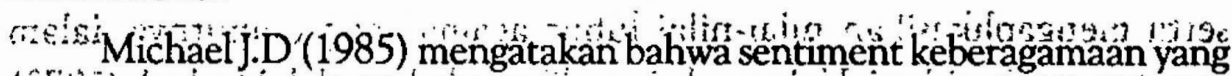
matang terarahkan secara konsisten. Individu yang matang dâlam beragama akan menyelaraskan nilai-nilai moral dengan ajần agamanya secâna

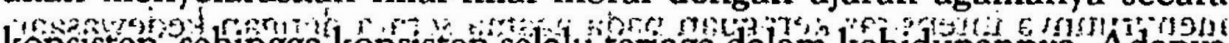
kônsisten, sehingga konsisten selallu terjaga dalam kehidupannya. Adanya konsisten individu dalam beragama dapat menjaga diri individu terjerumus ke dalam hal-hal yang dilarang dalam agama.

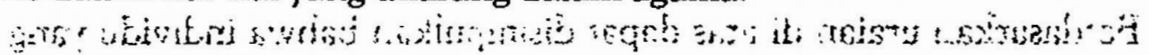

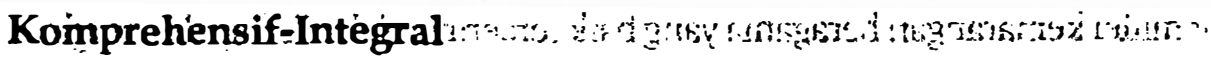

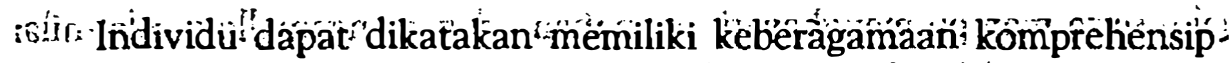

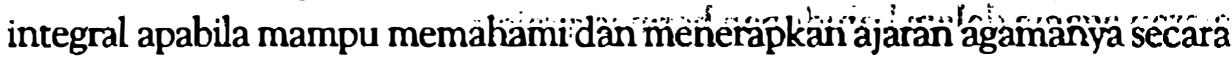

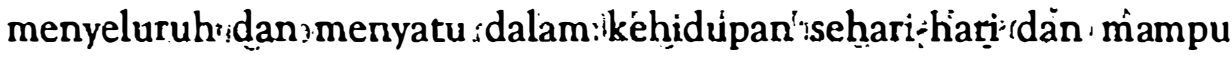
menyatukan aspek-aspek dalam agama dèngan laspek-áspek lain daläm kehidupan sehari-hari.

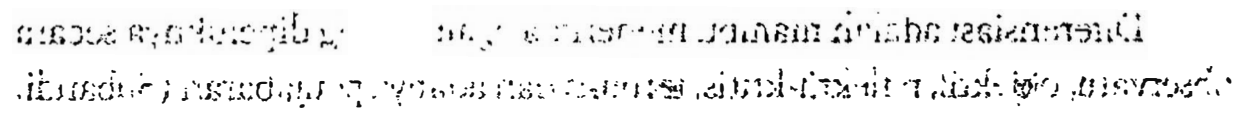

ientionsing

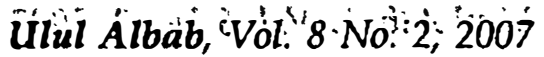




\section{Heuristik}

Heuristik artinya selalu berkembang, individu menyadari keterbatasannya dalam bergama dan selalu berusaha mencari dan meningkatkan pemahaman dan penghayatan dalam beragama.

\section{Kecerdasan Emosional}

Peter Salovey dari Harvard University dan John Mayer dari University of New Hampshire memperkenalkan istilah Emotional Intelligence atau Kecerdasan Emosional. Kecerdasan emosional selanjutnya dipopulerkan oleh Golemen dalam bukunya Emotional Intelligence.

Mayer dan Salovey (dalam Goleman, 1995) mendefinisikan kecerdasan emosional sebagai kemampuan merasakan, mengungkapkan, membangkitkan, memahami, dan mengendalikan emosi dalam rangka menunjukkan perkembangan emosi dan perkembangan intelektual. Menurut Goleman (2000), kecerdasan emosional adalah kemampuan untuk mengatur kehidupan emosi dengan inteligen, menjaga keselarasan dan mengungkapkan emosi melalui keterampilan kesadaran diri, motivasi diri, empati, dan keterampilan sosial.

Cooper dan Sawaf (2001) menyebutkan definisi kecerdasan emosi sebagaikemampuanmengindra, memahami dan menerapkan secara efektif kekuatan dan ketajaman emosi sebagai sumber energi, informasi, dan pengaruh.

Kecerdasan emosional akan membentuk kompetensi emosi dalam diri anak, yang akan membentuk kompetensi sosial. Anak yang kurang memiliki kompetensi sosial akan memperlihatkan respon emosi negatif, seperti kurang bahagia dan kurang ceria dalam bermain (Denham, dalam Gottman dkk, 1997). Penelitian Schutte, dkk (dalam Goleman, 1995) tentang kecerdasan emosional menunjukan bahwa subyek yang memiliki skor kecerdasan emosional yang tinggi, secara signifikan juga memiliki skor self-monitoring, skor empati, skor social-skill, skor hubungan interpersonal yang tinggi, dan memperlihatkan perilaku kooperatif serta kepuasan hati dalam perkawinan

Ulul Albab, Vol. 8 No. 2, 2007 
(marital satisfaction). Orang yang memiliki kecerdasan emosional mampu menyesuaikan diri dengan baik dan mempunyai keterampilam emosi (Gottman, dkk., 1997).

Berkaitan dengan uraian tersebut, kecerdasan emosional merupakan kemampuan seseorang dalam mengelola dan mengekspresikan emosi sesuai dengan kondisi yang terjadi. Kemampuan tersebut berupa kesadaran emosi, bagaimana mengungkapkan emosi secara tepat, motivasi diri, memahami orang lain, dan menjalin hubungan dengan orang secara harmonis.

Salovey (Goleman, 2000) mengemukakan lima ciri utama dari kecerdasan emosional.

a. Mengenali emosi diri. Kesadaran dalam mengenali perasaan ketika perasaan itu terjadi.

b. Mengelola emosi. Mengelola emosi agar dapat terungkap secarà tepat dan benar.

c. Memotivasi diri. Menumbuhkan dorongan dalam diri untuk mencapai tujuan dan mampu menyesuaikan diri dengan situasi baru.

d. Mengenal emosi orang lain. Kemampuan untuk merasakan perasaan orang lain dan mampu menangkap pesan-pesan nonverbal yang tersembunyi serta peka terhadap keinginan dan kehendak orang lain.

e. Membina hubungan. Kemampuan ini merupakan keterampilan sosial, yaitu bagaimana menjalin hubungan dengan orang lain secara harmonis, dan mampu mengirim isyarat emosional secara tepat.

\section{Daya Tahan Terhadap Stres}

Menurut Cridder (1983) daya tahan terhadap stres adalah kemampuan individu untuk bertahan dari stresor-stresor yang mengancam motif-motif dasar dan mengganggu kemampuan beradaptasi dengan fisiologis dan psikologis. 
Atwater (1983) mendefinisikan daya stres sebagai tingkat dan durasi stres yang dapat ditoleransi individu tanpa menjadi kacau dan irrasional atau merupakan ambang batas sebelum terjadinya perilaku yang tidak efisien dan pikiran yang irrasional.

Cameron \& Karganeth (dalam Rahman, 1996) mendefinisikan daya tahan stres sebagai kemampuan individu untuk menghadapi tekanan, hambatan, rintangan dan konflik tanpa menimbulkan reaksi maladaptif.

Dengan demikian dapat disimpulkan bahwa daya tahan terhadap stres adalah kemampuan individu untuk bertahan dari stresor-stresor yang mengganggu kehidupannya yang terlihat dalam reaksi fisiologis dan psikologis sebagai respon terhadap stres.

Stres yang dialami oleh individu akan menimbulkan gangguan dalam segala segi yaitu gangguan emosi, gangguan kognisi, dan gangguan fisiologis (Cridder, 1983).

Respon stres berbeda-beda pada setiap orang karena stres sifatnya sangat subyektif dan merupakan pengalaman pribadi. Namun setidaknya dapat ditemukan respon-respon tertentu yang menunjukkan bahwa seseorang mengalami stres, yaitu respon pada aspek emosi, fungsi pikir dan fisiologis. Sebaliknya orang yang memiliki daya tahan terhadap stres juga akan memiliki daya tahan emosi, fungsi pikir dan fisiologis pada waktu berada pada situasi yang menimbulkan stres (Widiantari, 2000).

Dari uraian di atas dapat disimpulkan bahwa individu yang mengalami stres akan mengalamigangguan emosi, gangguan fungsi pikir dan gangguan fisiologis. Sedangkan orang yang memiliki daya tahan terhadap stres memiliki daya tahan memiliki daya tahan emosi, fungsi pikir dan fisiologis pada waktu berada pada situasi yang menimbulkan stres.

\section{Hubungan antara Kematangan Beragama dengan Daya Tahan terhadap Stres}

Manusia sebagai makhluk sosial membutuhkan dukungan dari lingkungannya, oleh karena itu manusia selalu membutuhkan bantuan dari 
sesama manusia atau makhluk ciptaan Tuhan yang lainnya. Akan tetapi secara pribadi di dalam diri manusia terdapat suatu insting atau naluri untuk mengadakan penyembahan terhadap suatu kekuatan di luar diri manusia yang disebut dengan instink religius. Naluri inilah yang mendorong manusia untuk mengadakan suatu kegiatan yang bersifat religius. Secara instinktif ataupun secara rasional segala pengalaman kehidupan baik yang positif maupun negatif selalu dihubungkan dengan keseluruhan nilai kehidupan, dan Tuhan merupakan prinsip obyektif sebagai pengalaman pribadi.

Kematangan beragama pada diri individu juga akan membawa indivu pada suatu keyakinan bahwa selain berhubungan baik dengan Tuhannya dia juga harus berhubungan baik dengan dirinya dan orang lain. Bisa menerima kekurangan dan kelebihan yang dimilikinya sekaligus menerima kekurangan dan kelebihan orang di sekitarnya.

Menurut Darajat (1978), agama yang ditanamkan sejak dini kepada anak merupakan bagian dari unsur kepribadiannya, yang akan cepat bertindak sebagai pengendali dalam menghadapai segala keinginan dan dorongan yang timbul. Keyakinan terhadap agama akan mengatur sikap dan tingkah laku seseorang secara otomatis dari dalam.

Menurut Allport (Donahue, 1985) individu yang matang agamanya akan bersikap dinamis yaitu berperilaku yang terarah, terkontrol dan mengalami perubahan karena pengaruh agamanya. Hal ini memungkinkan individu untuk memiliki kemampuan kontrol diri yang baik.

Menurut Jalaluddin (1997) bahwa individu yang memiliki kematangan beragama akan terlihat dari kemampuannya untuk memahami, menghayati serta mengaplikasikan nilai-nilai luhur agama yang dianutnya dalam kehidupan sehari-hari. Hal senada juga dikemukakan oleh Hurlock (1973) bahwa perkembangan keagamaan yang terjadi pada remaja dicirikan dengan menurunnya intensitas keraguan pada agama setara dengan kedewasaan diri dalam menghadapi masalah secara objektif dan memecahkannya tanpa emosi. 


\section{Hubungan antara kecerdasan emosional dengan daya tahan terhadap stres}

Kecerdasan emosional merupakan kemampuan seseorang dalam mengelola dan mengekspresikan emosi sesuai dengan kondisi yang terjadi. Kemampuan tersebut berupa kesadaran emosi, bagaimana mengungkapkan emosi secara tepat, motivasi diri, memahami orang lain, dan menjalin hubungan dengan orang secara harmonis

Shapiro (1999) mengemukakan komponen kecerdasan emosional dalam buku How to Raise a Child with a Emotional Intelligence. Menurut Shapiro, terdapat beberapa komponen yang mempengaruhi keberhasilan seseorang dalam menjalani kehidupan, yaitu empati, mengungkapkan dan memahami perasaan, mengendalikan amarah, kemandirian, mampu menyesuaikan diri, disukai, dapat memecahkan masalah antar pribadi, ketekunan, kesetiakawanan, keramahan, dan sikap hormat kepada orang lain. Kecerdasan emosional merupakan salah satu faktor yang bisa membantu seorang individu dalam mengatasi berbagai permasalahan yang dihadapi dalam kehidupan sehari-harinya. individu yang memiliki kecerdasan emosional mampu menentukan dan memilih perilaku yang tepat dalam menghadapi berbagai macam persoalan yang dihadapi. Seorang individu yang memiliki kecerdasan emosional tinggi bisa memahami emosinya, bisa mengelola emosinya, bisa menyesuaiakan diri dengan orang lain dan lingkungan sekitarnya, dengan demikian orang yang memiliki kecerdasan emosional lebih tahan terhadap stres.

\section{Hipotesa Penelitian}

Hipotesis dalam penelitian ini adalah sebagai berikut:

1. Ada hubungan antara kematangan beragama dengan daya tahan terhadap stres

2. Ada hubungan antara kecerdasan emosional dengan daya tahan terhadap stres. 


\section{METODOLOGI PENELITIAN}

\section{Identifikasi Variabel}
a. Variabel Bebas
Kematangan beragama dan
Kecerdasan Emosional
b. Variabel Terikat :
Daya tahan terhadap stress

\section{Definisi Operasional}

Kecerdasan Emosional adalah kemampuan untuk menyadari, mengatur, dan menggunakan emosi secara efektif dalam hubungan intrapersonal dan antarpersonal.

Kematangan Beragama adalah internalisasi agama di dalam diri seseorang ditunjukkan dengan enam kriteria yaitu: terdeferesiensi dengan baik; dinamis; konsisten; komprehensif integral dan heuristik.

Daya tahan terhadap stres adalah kemampuan individu untuk bertahan dari stresor-stresor yang mengganggu kehidupannya yang terlihat dalam aspek emosi, fungsi pikir dan fisiologis sebagai respon terhadap stres.

\section{Populasi dan Sampel Penelitian}

Populasi penelitian ini adalah mahasiswa Fakultas Psikologi Universitas Islam Negeri (UIN) Malang. Sedangkan penentuan sampel penelitian menggunakan metode purposive sampling yang didasarkan pada karakterisuik tertentu.

Jumlah populasi sebanyak 304 mahasiswa, berdasarkan pendapat Arikunto (1997) yang mengatakan bahwa apabila jumlah subjek kurang dari 100 lebih baik diambil semua sehingga merupakan penelitian populasi, sedangkan apabila jumlah subjek lebih besar maka dapat diambil 10-15\% atau 20-25\%.,maka dalam penelitian ini sumlah sample ditentukan sebanyak $20 \%$ dari populasi yang ada yaitu 60 orang. 


\section{Metode pengumpulan data}

Dalam penelitian ini pengumpulan data dilakukan dengan menggunakan skala, yaitu: pertama, Skala kecerdasan emosional, yaitu skala yang mengukur kecerdasan emosional. Kedua, skala kematangan beragama, yaitu skala yang mengukur tingkat kematangan beragama. Kedua skala menggunakan skala Likert, dengan alternatif respon sangat sesuai, sesuai, tidak sesuai dan sangat tidak sesuai. Pembobotan dari jawaban positif adalah jawaban sangat sesuai diberi nilai 4, jawaban sesuai diberi nilai 3, jawaban tidak sesuai diberi nilai 2 dan jawaban sangat tidak sesuai diberi nilai 1 . Sebaliknya pembobotan jawaban negatif adalah, sangat tidak sesuai diberi nilai 4, jawaban tidak sesuai diberi nilai 3, jawaban sesuai diberi nilai 2 dan jawaban sangat sesuai diberi nilai 1 . Ketiga, skala daya tahan terhadap stress yaitu skala yang mengukur daya tahan terhadap stress. Skala ini diadaptasi dari Skala Daya Tahan Stres yang disusun oleh Widiantari (2000). Teknik penskalaan menggunakan skala Likert, dengan alternatif respon selalu, sering, jaran, tidak pernah. Pembobotan dari jawaban positif adalah jawaban selalu diberi nilai 4, jawaban sering nilai 3, jarang diberi nilai 2 dan jawaban tidak pemah diberi nilai 1 . Sebaliknya pembobotan jawaban negatif adalah, selalu diberi nilai 1 , jawaban sering diberi nilai 2, jawaban jarang diberi nilai 3 dan jawaban tidak pernah diberi nilai 4 .

\section{Uji Validitas dan Uji Reliabilitas Validitas}

Penentuan validitas aitem menggunakan koefisien korelasi $\geq 0,200$ dan taraf signifikansi sebesar 0,001 . Koefisien korelasi yang sama atau lebih besar dari 0,200 dan signifikansinya lebih besar dari 0,001, maka aitem tersebut dianggap valid dan layak digunakan dalam penelitian ini. Uji validitas dalam penelitian ini menggunakan program SPSS versi 13.00

\section{Reliabilitas}

Reliabiltas dinyatakan dalam koefisien reliabilitas, dengan angka antara 0 sampai 1,00. semakin tinggi koefisien mendekati angka 1,00 berarti 
reliabilitas alat ukur semakin tinggi. Sebaliknya reliabilitas alat ukur yang rendah ditandai oleh koefisien reliabilitas yang mendekati angka 0 (Azwar, 1999).Prosedur pengujian reliabilitas dalam penelitian ini menggunakan program SPSS versi 13.00 .

\section{Metode Analisa Data}

Untuk menguji hipotesis pertama dan kedua menggunakan teknik analisa korelasi product moment, yang dibantu program SPSS versi 13 .

\section{HASIL PENELITIAN Hasil Uji Validitas dan Reliabilitas}

Hasil uji validitas alat ukur yang mengungkap kematangan bergama dengan menggunakan korelasi product moment diperoleh hasil dari 40 butir ada 7 butir yang gugur dan 32 butir yang sahih. Pada skala kecerdasan emosional, dari 40 butir yang ada satu butir yang gugur dan 39 butir sahih. Sedangkan pada skala daya tahan terhadap stres dari 34 butir yang gugur sebanyak 1 butir dan 33 butir sahih.

Hasil uji reliabilitas alat ukur yang menggunakan teknik Alpha Cronbach diperoleh hasil bahwa skala kematangan beragama dinyatakan andal dengan rtt sebesar 0,838 , skala kecerdasan emosional andal dengan $\mathrm{rtt}$ sebesar 0,914 dan skala daya tahan terhadap stress juga andal dengan rtt sebesar 0,869.

\section{Korelasi antara kematangan beragama dengan daya tahan terhadap stres}

Hasil analsis yang diperoleh dari perhitungan dengan menggunakan analisa korelasi product moment antara kematangan beragama dengan daya tahan stres diperoleh $p=0,029$. ini berarti terdapat korelasi positif antara kematangan beragama dengan daya tahan terhadap stress $(p<0,050)$. Hal ini menunjukkan semakin tinggi kematangan bergama seseorang, maka semakin tinggi pula daya tahan terhadap stress. 


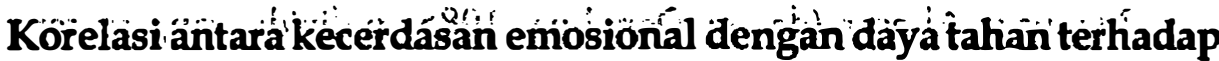
stres

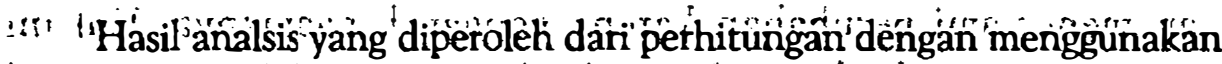

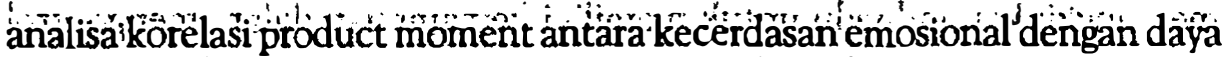
tahan terhádap stres diperoleh $\mathrm{p}=0,000$ ini berarti terdapat korelasi positif antara kecerdasan èmosiónal dengán dàya tahan terhadap stress $(\dot{p}<0,050)$. Hal ini menunjukkan semakin ónggikecerdasan emósiónal seseorang; maḱa semakin tinggi pula daya tahan terhadapistress: 34 ,

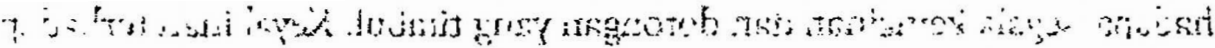

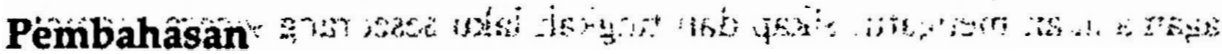

Hasil analisis hipotesis pertama menunjukkan bahwa kematangán

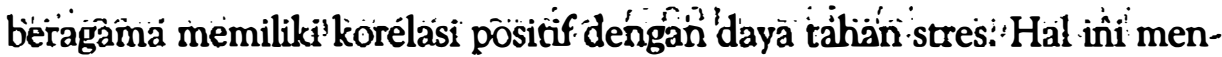

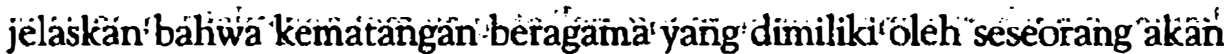

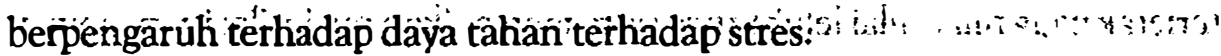

$\therefore$ senelitian ini sejalan dengan hasil penelitian Stinnet dan DeFrain (Hawari, 1997$)^{2}$ yang menyebutkan bahio kểidupan beragama dalam keluarga, ketaatan menjalankan ibadah, dan remàja yang dibesarkan dalạn keluarga yang tidak religius memilik resiko yang lebihbesar untuk terlibat dálam penyalăhgunaan obat-obat terlarang. Dimana penyalahgunaan narkoba yan terjadi disebaban remaja tidák dapâ mengelóla strè yang disebabkan ketidakmampuan menghadapi konflik dan ketegangan yañg

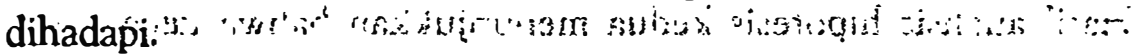

"Temuan Wimbarti (Djuwarijah, 2000) bahwa anak nonagresi senan tiasa mengadakan kegatan agama, shálat jamaah setiaphari bersama ke

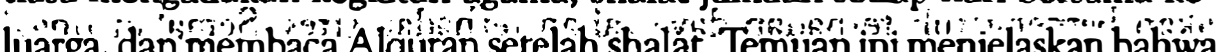
luarga, dan mernbaca Alquuran setelah shalát. Temuan ini menjelaskan bahwa suasana agamis di pesantren métniliki peran menurunkan agrèsivitas yang dapat menyebabkan perilaku menyimpang.

Meichati (dalam Subandi, 1988 ) juga mengatakan kehidupan kèberagamaan memberikan kékuatañ jiwa seseorang untuk menghadapi tantangan dan côbaan hidụp, memberikan bantuan mòtal dâlám menghadapi krisis sèrta mennimbullkan sikap rêla menerima kenyataan yang télăh ditakdirkan Tuhan.

ứlul Albáb, Voll. 8 Nó? $2,200 \%$ 
Menurut Allport (dalam Donahue, 1985) individu yang matang agamanya akan bersikap dinamis yaitu berperilaku yang terarah, terkontrol dan mengalami perubahan karena pengaruh agamanya. Hal ini memungkinkan individu untuk memiliki kemampuan dalam mengontrol perilaku termasuk ketika sedang menghadapi suatu permasalahan.

Sejalan dengan itu Darajat (1978) berpendapat bahwa agama yang ditanamkan sejak dini kepada anak merupakan bagian dari unsur kepribadiannya, yang akan cepat bertindak sebagai pengendali dalam menghadapai segala keinginan dan dorongan yang timbul. Keyakinan terhadap agama akan mengatur sikap dan tingkah laku seseorang secara otomatis dari dalam.

Menurut Jalaluddin (1997) bahwa seseorang yang memiliki kematangan beragama mampu mengenali atau memahami nilai agama yang terletak pada nilai-nilai leluhurnya serta menjadikan nilai-nilai itu pedoman dalam bersikap dan bertingkah laku dalam kehidupan sehari-hari. Termasuk ketika menghadapi masalah dalam kehidupannya. Ketika menghadapi permasalahan invividu yang matang agamanya cenderung lebih berpikir positif dibangingkan individu yang tidak memiliki kematangan bergama. Hal ini disebabkan dalam agama diajarkan bahwa ketika menghadapi situasi yang berada di luar kemampuannya individu disuruh menyerahkan kepada sang pencipta.

Hasil analisis hipotesis kedua menunjukkan bahwa kecerdasan emosional memiliki korelasi positif dengan daya tahan stres. Hal ini menjelaskan bahwa kecerdasan emosional yang dimiliki yang dimiliki oleh seseorang akan berpengaruh terhadap daya tahan terhadap stres. Semakin tinggi kecerdasan emosional yang dimiliki seseorang semakin tinggi pula daya tahan stres orang tersebut.

Hal ini didukung oleh penelitian Hasanah (2003) yang mengatakan bahwa terdapat hubungan yang signifikan antara kecerdasan emosional dengan penyesuaian social. bahwa siswa yang mempunyai kecerdasan emosional yang rendah cenderung mengalami kesulitan dalam bergaul serta kurang mampu mengendalikan emosi.

Ulul Albab, Vol. 8 No. 2, 2007 
Hal senada dengan Patton (2000) yang mengatakan bahwa dengan kecerdasan emosi seseorang dibekali kompetensi-kompetensi untuk menghadapi kemalangan dan mempertahankan semangat hidup.

Menurut Goleman (2000) bahwa seni yang mantap untuk menjalin hubungan membutuhkan kematangan dalam ketrampilan emosional yaitu manajemen diri . individu dapat berhasil menjalin hubungan dengan orang lain apabila individu tersebut sudah mengenal dan mampu mengelola emosi dirinya terlebih dahulu, karena dengan mengenal emosi dan mengelola emsoi individu dapat menyesuaikan diri dengan lingkungannya. Individu yang mempunyai kemampuan menyesuaikan diri dengan lingkungannya cenderung lebih bias mengelola stress dan memiliki daya tahan stress yang lebih tinggi dibandingkan dengan individu yang memiliki kemampuan menyesuiakan diri dengan lingkungan yang rendah

\section{Kesimpulan}

Berdasarkan hasil penelitian yang telah dilakukan, maka dapat disimpulkan bahwa

1. Terdapat hubungan positif antara kematangan beragama dengan daya tahan terhadap stres. Hubungan positif ini menunjukkan adanya hubungan searah, yaitu kenaikan kematangan beragama secara proporsional diikuti dengan kenaikan daya tahan terhadap stres. Berdasarkan pernyataan tersebut, dapat disimpulkan bahwa semakin tinggi skor kematangan beragama yang diperoleh mahasiswa, makin tinggi pula daya tahan terhadap stres.

2. Terdapat hubungan positif antara kecerdasan emosional dengan daya tahan terhadap stres mahasiswa. Hubungan positif ini menunjukkan adanya hubungan searah, yaitu kenaikan kecerdasan emosional secara proporsional diikuti dengan kenaikan daya tahan terhadap stres. Berdasarkan pernyataan tersebut, dapat disimpulkan bahwa semakin tinggi skor kecerdasan emosional yang diperoleh mahasiswa, makin tinggi pula daya tahan terhadap stres.

Ulul Albab, Vol. 8 No. 2, 2007 


\section{DAFTAR PUSTAKA}

Batson, D.C, Oleson, K.C., Weeks, J.L, Healy S.P \& Reeves,P.J. 1989. Religious Prosocial Motivation: Is Altruistic or Egoistic/, Joumal of Personality and Social Psychology, 52, 873-884.

Cridder, A.B, Goethals, G.R, Kavanough, R. D. dan Solomon, P. R. 1983. Psychology. Scoot Foresman And Company. New York.

Darajat. Z. 1978. Problem Remaja Di Indonesia. Jakarta: Bulan Bintang. 1985. Membina Nilai-nilai Moral Di Indonesia. Jakarta: Bulan Bintang.

Dister, N.S. 1982. Pengalaman dan Motivasi Beragama, Pengantar Psikologi Agama. Jakarta: Leppmas.

Djuwarijah. 2000. Hubungan antara Kecerdasan Emosional dan Pengasuhan Islami dengan Agresivitas Remaja. Tesis. Yogyakarta: Pascasarjana Universitas Gadjah Mada.

Donahue, M.J. 1985. Intrinsic and Extrinsic Religiousness: Review and MetaAnalysis. Joumal of Personality and Social Psychology, 48, 400-419

Glock, C.Y. \& Stark, R 1966. Religion. Society in Transition. Chicago: Rand McNally and Company.

Goleman, D. 1995. Working with EQ. London: Clays Ltd. St Ives plc.

Goleman, D. 2000. Keceradasan Emosional. Alih Bahasa: Hermaya, T. Jakarta: PT Gramedia Pustaka Utama.

Gottman, J. \& Decline, J. 1997. Kiat-kiat Membesarkan Anak Yang Memiliki Kecerdasan Emosional. Jakarta: Gramedia Pustaka Utama.

Hawari. D. 1997. Al-Qur'an Ilmu Kedokteran Dan Kesehatan Jiwa. Yogyakarta: Dana Bhakti Prima Yasa.

Hurlock, E.B. 1973. Adolescent Development. Tokyo: Mc Graw Hill Kogakusha. Ltd.

Jalaluddin. 1997. Psikologi Agama. Jakarta: PT Raja Grafindo Persada.

Kalam Mulia.

$\propto$ Ramayulis, S. 1993, Pengantar Ilmu Jiwa Agama. Jakarta:

Kartono, K. 1986. Peran Keluarga Mernandu Anak. Jakarta: CV. Rajawali. Koeswara, E. 1988. Agresi Manusia. Bandung: PT Eresco. 
Monly. 1977. Current Perspectives in The Psychology of Religion. Michigan: William B. Bordmons Publishing Co.

Paloutzian, R.F. 1996. Invitation to The Psychology of Religion. Second Edition. Boston: Allyn and Bacon.

Rahman, A. A. 1996. Hubungan Antara Kebermaknaan Hidup dan Daya Tahan Terhadap Stres Pada Remaja. Skripsi. Tidak diterbitkan. Yogyakarta: Fakultas Psikologi UGM.

Rahmat, J. 1994. Islam Alternarifi cetamah-ceramah di Kampus. Bandung: Mizan.

Spinke, E.S. 1963. Psychology and Religion. London: Metheven \& Co Ltd. Subandi. 1995. Perkembangan Kehidupan Beragama. Buletin Psikologi. III (1), 11-35

1988. Hubungan Antara Tingkat Religiusitas dengan Kecemasan Pada Remaja. Laporan Penelitian (tidak terbit.) Yogyakarta: UGM.

Thouless, R.H. 1992. Pengantar Psikologi Agama (Terjemah: Machnum Husein). Jakarta: Rajawali Press.

Walgito, B. 2002 . Pengantar Psikologi Umum. Yogyakarta: Andi Offset.

Widiantari, A. 2000. Daya Tahan Stres Remaja ditinjau dari dukungan sosial keluarga dan Locus Of Control. Skripsi. Tidak Diterbitkan. Yogyakarta: Fakultas Psikologi UGM.

Yusuf, S. 2001. Psikologi Perkembangan Anak dan Remaja. Bandung: PT Remaja Rosdakarya. 